\title{
Kebijakan Non Penal terhadap Pelaku Tindak Pidana Perjudian Jenis Sabung Ayam dalam Wilayah Hukum Kepolisian Sektor Kota Baru
}

\author{
Hisbah* \\ Fakultas Hukum Universitas Baranghari Jambi \\ *Correspondence email: hisbah.ubr2013@gmail.com
}

\begin{abstract}
Abstrak. Perjudian ialah sebuah penyakit masyarakat yang mengamcam secara nyata atau berpotensial terhadap norma-norma sosial sehingga bisa mengancam berlangsungnya ketertiban umum. Tujuan penelitian ini ialah untuk mengetahui kebijakan hukum pidana dalam menanggulangi tindak pidana perjudian jenis sabung ayam dalam Wilayah Hukum Kepolisian Sektor Kota Baru saat ini dan yang akan datang, mengetahui kebijakan aplikatif yang dilakukan pihak penegak hukum untuk menanggulangi tindak pidana perjudian jenis sabung ayam di Wilayah Hukum Kepolisian Sektor Kota Baru. Dalam penelitian ini Penulis menggunakan metode penelitian yuridis empiris. Kebijakan hukum pidana penanggulangan perjudian jenis sabung ayam di Kitab UndangUndang Hukum Pidana judi telah diatur pada Pasal 303 bis dan aturan perida pidananya ialah empat tahun penjara. Yang mana perjudian ialah sebuah permainan yang mempertaruhkan benda berharga ataupun uang untuk taruhan. Peristiwa ini yang meebuat perjudian sebagai sebuah tindak pidana sebab masing-masing permainan yang dilaksanakan dengan memakai uang untuk taruhan itu disebut dengan perjudian. Sedangkan untuk yang akan mendatang yaitu dengan dilakukan pembaharuan pada Rancangan Undang-Undang KUHP adalah sebuah keharusan sebab pemerintah harus menyikapi perkembangan tersebut dengan merencanakan suatu aturan yang bisa mencakup serta dapat mengurangi kejahatan di bidang kesusilaan terutama tindak pidana perjudian jenis sabung ayam. Sehingga, hal semacam ini dibutuhkan kemitraan antara penegak hukum dengan anggota masyarakat dalam menanggulangi tindak pidana Perjudian supaya menciptakan keadaan sosial yang aman dan bersih dari perjudian yang meresahkan masyarakat. Kebijakan penerapan hukum yang dilakukan oleh aparat penegak hukum dalam upaya penanggulangan tindak pidana perjudian jenis sabung ayam di wilayah hukum Kepolisian Sektor Kota Baru dilakukan dengan upaya pre-emtif yaitu dengan memfokuskan pada upaya dengan himbauan pada para pelaku perjudian jenis sabung ayam supaya memiliki kesadaran serta tidak melaksanakan perjudian lagi sebab kemungkinan akan mengganggu keamanan dan ketertiban masyarakat sekitar. Kemudian dengan upaya preventif untuk penanggulangan sebagai dasar dalam memberantas tindak pidana perjudian di Wilayah Hukum Kepolisian Sektor Kota Baru. Selanjutnya melalui upaya Represif yang merupakan suatu tindakan yang dilakukan secara langsung untuk memberantas kejahatan dengan memberikan tindakan agar pelaku jera dan tidak mengulangi kejahatannya kembali.
\end{abstract}

Kata Kunci: Kebijakan; Non Penal; Pelaku; Perjudian Sabung Ayam

Abstract. Gambling is a social disease that threatens real or potential social norms so that it can threaten public order. The purpose of this study is to determine the criminal law policy in tackling the criminal act of cockfighting in the Kota Baru Sector Police Law Area at this time and in the future, to find out the applicable policies carried out by law enforcers to tackle the criminal act of cockfighting gambling in the Legal Territory. New City Sector Police. In this study the author uses empirical juridical research methods. The criminal law policy against cockfighting gambling in the Criminal Code of gambling has been regulated in Article 303 bis and the penal code is four years in prison. Which is gambling is a game that puts valuable objects or money for betting. This incident makes gambling a criminal offense because any play that is played using money for betting is called gambling. Meanwhile, for the future, namely reforming the Draft Criminal Code is a must because the government must respond to these developments by planning a regulation that can include and reduce crimes in the field of decency, especially the crime of gambling in the type of cockfighting. So, this kind of thing requires a partnership between law enforcers and community members in overcoming the criminal act of gambling in order to create a social situation that is safe and clean from gambling that is troubling the public. The policy of law enforcement carried out by law enforcement officials in an effort to combat the crime of cockfighting gambling in the New City Sector Police jurisdiction is carried out by pre-emptive efforts, namely by focusing on efforts with an appeal to perpetrators of cockfighting gambling so that they have awareness and not. carry out gambling again because it is likely to disturb the security and order of the surrounding community. Then with preventive measures for prevention as a basis for eradicating gambling crimes in the New City Sector Police Legal Territory. Furthermore, through repressive measures, which are actions taken directly to eradicate crime by taking action so that the perpetrator is deterred and does not repeat the crime again.

Keywords: Policy; Non Penal; Perpetrators; Cockfighting Gambling

\section{PENDAHULUAN}

Negara Kesatuan Republik Indonesia adalah negara yang berdasar atas hukum (rechtsstaat) dan bukan negara atas kekuasaan (machtsstaat), maka kedudukan hukum harus ditempatkan di atas segala- galanya. Setiap perbuatan harus sesuai dengan aturan 
hukum tanpa kecuali. ${ }^{1}$ Ketetapan MPR No. IV/MPR/1999 tentang Garis Garis Besar Haluan Negara (GBHN), telah menentukan arah kebijakan di bidang hukum khususnya mengenai sistem hukum nasional yang menyeluruh dan terpadu dengan mengakui dan menghormati hukum agama dan hukum adat, serta memperbaharui perundang-undangan warisan Belanda dan hukum nasional yang diskriminatif termasuk ketidakadilan gender dan ketidaksesuaiannya dengan tuntutan reformasi melalui program legislasi.

Hukum memiliki tugas dalam mengkoordinasikan dan mengintegrasikan seluruh kepentingan masingmasing personal di masyarakat. Dengan harapan semua kepentingan yang saling berkaitan bisa selaras serta tidak saling bertolak belakang. Dalam meraih tujuan tersebut bisa dilaksanakan malalui pembatasan serta memberikan perlindungan untuk kepentingan tersebut. Walaupun berbagai perbuatan dan perilaku yang sudah ada dalam perpu, akan tetapi kriminal tetap saja banyak terjadi di negara ini seperti tindak pidana perjudian. Sedangkan sejak dahulu perjudian sudah ada dan dengan perkembangan zaman perjudian juga semakin maju. Encyclopedia Britanica mendata bahwa perjudian sudah ada sejak pada zaman primitif, contohnya suku Bushmen di Afrika Selatan, suku Aborigin di Australia dan suku Indian di Amerika, yang mana mereka sudah kenal dengan permainan dadu. ${ }^{2}$ Selanjutnya perkembangan judi sudah sejak zaman Yunani Kuno. Bermacammacam teknik dan permainan judi yang mudah menjadikan judi dengan mudah berkembang ke seluruh penjuru dunia termasuk Indonesia.

Kriminalitas atau jenis kejahatan banyak jenisnya, dari kriminal yang merugikan negara, memakan korban jiwa sampai meresahkan masyarakat ataupun merusak ketertiban umum. Kriminal yang banyak ada di masyarakat awam ialah kriminal yang meresahkan masyarakat atau merusak ketertiban umum. Contoh kriminal yang meresahkan masyarakat ialah aktivitas perjudian.

Perjudian ialah sebuah penyakit masyarakat yang mengamcam secara nyata atau berpotensial terhadap norma-norma sosial sehingga bisa mengancam berlangsungnya ketertiban umum. Sehingga perjudian bisa menghambat pembangunan nasional yang tertuju sumber daya manusia. Dengan demikian perjudian harus ditangani dengan cara yang rasional. Salah satu usaha yang rasional tersebut adalah dengan pendekatan kebijakan hukum pidana. Hukum pidana digunakan untuk menyelesaikan masalah sosial khususnya dalam menangani kejahatan sebagai salah satu bentuk penyakit masyarakat dan satu bentuk patologi sosial seperti kasus

${ }^{1}$ Nyoman Serikat Putra Jaya,Relevansi Hukum Pidana Adat Dalam Pembaharuan Hukum Pidana Nasional, PT Citra Aditya Bakti, Bandung, 2005. hlm 3 - 4.

${ }^{2}$ Anton Tabah, 1991, Menatap Dengan Mata Hati Polisi Indonesia, PT Gramedia Pustaka Utama, Jakarta, hlm. 181. perjudian. Penegak hukum pidana untuk menangani perjudian sebagai perilaku menyimpang yang harus terus dilakukan.

Judi dapat diartikan sebagai permainan yang menggunakan barang berharga ataupun uang untuk pertaruhan (seperti bermain kartu dan dadu), perjudian liar (contoh tebak nomor akhir dari undian resmi). Secara umum perjudian ialah sebuah permainan yang memakai taruhan dengan karakteristik yaitu untunguntungan, dalam memperoleh menang dibutuhkan keahlian adalam permainan. Apabila orang yang ikut bermain mengalami kekalahan dalam taruhan maka dia harus memberi taruhannya pada pemain yang menang. Contoh aktivitas yang disalahgunakan oleh masyarakat yakni judi jenis Sabung Ayam. Sabung ayam ialah aktivitas berbentuk perjudian yang ada dari zaman dahulu sampai saat ini masih banyaknya dilakukn di masyarakat. Sabung Ayam dapat diartikan "Adu Dua Ekor Ayam" sesungguhnya mempunyai historis yang tidak sama di masing-masing wilayah di Indonesia. Sabung Ayam termasuk dalam bentuk folklore, yang dinamakan permainan rakyat yang terkenal dibeberapa wilayah di dunia contohnya Kanada, Taiwan, Perancis, Indinesia, Jepang, Filipina, dan lainnya. ${ }^{3}$

Di Indonesia, sejarah aktivitas mengadu 2 ekor ayam jantan/jago ataupun dinamakan Perjudian Sabung Ayam merupakan sebuah kegemaran ataupun akitivitas yang kenal serta terkenal pada lingkup kemasyarakatan. Bukan hanya dianggap kegemaran, kegiatan tersebut juga sering menjadi media ataupun ajang judi dalam skala besar ataupun kecil yang jumlah taruhannya hingga puluhan juta. Dikarenakan sering diiringi modus perjudian, dengan demikian polisi sebagai pihak selaku penegak hukum senantiasa melakukan pengawasan serta merazia semua aktivitas Sabung Ayam yang dilaksanakan. Terdapat pergerakan kebudayaan ataupun kegemaran menjadi suatu judi dikarenakan ada banyak jenis.

Terdapat sejumlah permasalahan yang muncul karena kegiatan tersebut, yakni bahwa sejumlah individu jadi candu, orang-orang yang melakukan hal tersebut tidak bisa memberhentikan kegiatan perjudiannya lalu berujung banyak harta ataupun uang yang hilang. Maka sangat jelas bahwa di samping memberi kerugian pada diri sendiri, nyata bisa pula memberi kerugian pada masyarakat sebab dapat mengganggu kejiwaan suatu individu serta mengganggu perekonomian masyarakat secara keseluruhan. Di samping adanya kerugian pada kesehatan, mental, serta uang, ternyata juga membuat orang yang terlibat judi menjadi malas untuk melakukan kegiatan lain, sehingga menjadi sering melakukan

${ }^{3}$ https://id.scribd.com/doc/99081468/Seluk-BelukAyam-Adu-unggas-Pada-Umumnya, diakses pada tanggal 1 Maret 2021 
perbuatan yang bersifat kriminalitas, contohnya pembunuhan, pencurian, serta korupsi. ${ }^{4}$

Praktek perjudian itu harus ditangani sebab pada Kitab Undang-undang Hukum Pidana bab XVI, perjudian masuk kategori kriminalitas pada kesopanan yang maka dampak berdasarkan diperbuatnya tindakan tersebut berakibat terhadap ketertiban masyarakat. Regulasi mengenai larangan perjudian pada sistim hukum Indonesia yakni di luar Kitab Undang-undang Hukum Pidana \& di dalam Kitab Undang-undang Hukum Pidana. Dalam Kitab Undang-undang Hukum Pidana dibahas pada Pasal 303 serta Pasal 303bis Kitab Undang-undang Hukum Pidana serta diperkuat melalui dengan UU Nomor 7 Tahun 1974 mengenai Penertiban Perjudian, yang termasuk perjudian dengan cara konvensional. Pada pasal 303 KUHP menerangkan bahwa pelaku perjudian akan mendapat hukuman pidana yang sesuai pasal 303 yaitu:

Diancam dengan pidana penjara paling lama sepuluh tahun atau pidana denda paling banyak dua puluh lima juta rupiah, barang siapa tanpa mendapat izin: (1) dengan sengaja menawarkan atau memberikan kesempatan untuk permainan judi dan menjadikannya sebagai pencarian, atau dengan sengaja turut serta dalam suatu perusahaan untuk itu; (2) dengan sengaja menawarkan atau memberi kesempatan kepada khalayak umum untuk bermain judi atau dengan sengaja turut serta dalam perusahaan untuk itu, dengan tidak peduli apakah untuk menggunakan kesempatan adanya sesuatu syarat atau dipenuhinya sesuatu tata-cara; (3) menjadikan turut serta pada permainan judi sebagai pencarian.

Pada praktik perjudian selaku sebuah tindak pidana, sifat perbuatannya yang bertentangan terhadap hukum bisa dihilangkan apabila perbuatan tersebut memperoleh perizinan dari pihak yang berwenang maka judi dapat dianggap legal ataupun sah. Selain itu, pernyataan itu didukung oleh Peraturan Pemerintah Nomor 9 Tahun 1981 mengenai Implementasi Undangundang Nomor 7 Tahun 1974 yang diperuntukkan pada Pemda \& Pemerintah Pusat untuk mencabut perizinan ataupun melarang judi dengan tujuan ataupun bentuk apapun. Seluruh regulasi itu diasumsikan selaku perangkat hukum secara pasti dalam mencabut izin aktivitas perjudian. Sehingga untuk menjaga ketertiban masyarakat dan menegakan hukum, pihak kepolisian selaku penegak hukum \& aparatur negara memiliki peranan untuk mengatasi tindak pidana tersebut.

Permasalah kejahatan perjudian sabung ayam yang berlangsung pada hari rabu tanggal 24 Juni 2020, peristiwa tersebut terjadi di sekitar Kelurahan Bagan Pete Kecamatan Alam Berajo Kota jambi dimusnahkan

${ }^{4}$ Anton Tabah, Op.Cit., hlm. 182. dengan cara dibakar oleh polisi Kotabaru. Pada waktu akan dibakar, tim Kepolisian Sektor Kotabaru secara diam-diam mendatangi tempat kejadian. Selanjutnya, tim tersebut mengrebek tempat yang telah diduga mengkhawatirkan masyarakat sekitar. Tapi ketika dirazia pihak kepolisian, lokasi itu tidak ditemui pemain judinya, yakni sudah kosong. Walaupun terlihat kosong, Kepala Kepolisian Sektor Kotabaru AKP Afrito Marbaro langsung memerintah anggotanya agar membakar lokasi itu. Polisi membakar sejumlah kursi duduk, atap, dan tempat duduk perjudian tersebut lalu sebelumnya dirusakkan lalu pihak kepolisian membakarnya. Kobaran api semakin besar lalu membakar seluruh lokasi perjudian itu. Polisi akan bertindak tegas untuk bagi pelaku usaha judi pada Wilayah Hukum yang dinaunginya.

Pemakaian kebijakan hukum kategori hukum pidana, menjadi sebuah cara dalam menanggungi permasalahan yakni contohnya untuk menegakkan hukum. Selain hal tersebut, dikarenakan memiliki tujuan menjunjung tinggi HAM dan mewujudkan kesejahteran masyarakat, sehingga kebijakan hukum tersebut masuk kategori kebijakan sosial, yakni seluruh upaya secara logis rasional dalam mewujudkan masyarakat yang sejahtera.

Meskipun adanya larangan serta ancaman dalam perjudian dengan hukum, akan tetapi pelanggaran terhadap hal tersebut masih banyak. Peristiwa tersebut disebabkan banyak anggota masyarakat yang memiliki keinginan yang perlu dicukupi dengan berjudi ialah salah alternatif yang harus dijalankan walaupun mereka mengetahui resikonya.

\section{Rumusan Masalah}

Pada pembahasan skripsi ini agar mendapatkan pembahasan yang terarah serta sistematik berdasarkan maksud yang diinginkan penulis membatasi masalahnya yaitu:

1. Bagaimana kebijakan hukum pidana untuk menanggulangi tindak pidana perjudian jenis sabung ayam dalam Wilayah Hukum Kepolisian Sektor Kota Baru saat ini dan yang akan datang ?

2. Bagaimana kebijakan penerapan hukum yang dilakukan oleh aparat penegak hukum untuk menanggulangi tindak pidana perjudian jenis sabung ayam di Wilayah Hukum Kepolisian Sektor Kota Baru?

\section{METODE}

\section{Jenis Penelitian}

Penelitian ini adalah jenis penelitian yuridis empiris, ataupun biasanya dikatakan penelitian lapangan yaitu melakukan pengkajian hukum yang berjalan dan sesuatu yang timbul pada realitanya terhadap lingkup kemasyarakatan.

Penelitian yuridis empiris ialah penelitian hukum berhubungan dengan penerapan ataupun pelaksanakaan 
kebijakan hukum normatif dengan cara in action di tiaptiap suatu fenomena hukum tertentu yang timbul pada lingkup kemasyarakatan ${ }^{5}$. Atau dapat dikatakan juga yaitu sebuah penelitian yang dilaksanakan pada situasi sesunggunya ataupun kondisi fakta yang dialami pada masyarakat yang bertujuan dalam menemukan serta mengetahui data serta fakta-fakta yang diperlukan, sesudah bahan yang diperlukan diperoleh lalu lanjut ke pengidentifikasian permasalahan yang berujung menyelesaikan permasalahan. ${ }^{6}$

\section{Pendekatan Penelitian}

Dalam penelitian ini pendekatan yang dipakai untuk memecahkan masalah yakni dengan menggunakan metode pendekatan yuridis empiris. Pendekatan yuridis yang dimaksud ialah hukum dipandang selaku norma atau das sollen), sebab untuk membahas permasalahan digunakanan sumber-sumber hukum (secara tertulis ataupun tidak dan bahan hukum sekunder ataupun primer, tersier, ataupun sekunder). Sementara pendekatan empiris yakni melalui pandangan hukum selaku das sein, realita sosial, serta kultural dikarenakan hal ini menggunakan data primer yang didapatkan saat melakukan penelitian.

Maka dari itu, pada penelitian ini pendekatan yuridis empiris yang dimaksud ialah bahwasannya untuk melakukan analisis terhadap masalah yang sudah dikumpulkan melalui perpaduan bahan hukum secara tersier, primer, atauoun sekunder. Data primer yang didapatkan pada penelitian yakni mengenai kebijakan non penal terhadap pelaku tindak pidana judi jenis sabung ayam dalam wilayah hukum Polsek Kota Baru.

\section{Jenis dan Sumber Data}

Pada penelitian dengan pendekatan yuridis, ditinjau berdasarkan cara pemerolehan serta pengumpulan bahan digolongkan menjadi 2 jenis, yakni data sekunder \& primer. Data primer merupakan bahan yang diperoleh berdasarkan sumber pertama yang berhubungan terhadap masalah dan hendak diwawanca dengan cara terstruktur yakni pada pihak terkait. Sedangkan data sekunder didapatkan penelaahan pada bahan yang dipakai mencakup bahan hukum tersier, primer, serta sekunder. Sementara itu, data hukum sekunder yaitu perundang-undangan dan peratutan yang berlaku, sedangkan data hukum tersier yakni jurnal hukum dan beberapa artikel yang relevan dengan penelitian. ${ }^{7}$

\footnotetext{
${ }^{5}$ Abdulkadir Muhammad, Hukum dan Penelitian Hukum, Citra Aditya Bakti, Bandung, 2004, hlm 134

${ }^{6}$ Bambang Waluyo, Penelitian Hukum Dalam Praktek, Sinar Grafika, Jakarta, 2002, hlm. 15

${ }^{7}$ Soerjono Soekanto dan Sri Mamuji, Penelitian Hukum Normatif 'Suatu Tinjauan Singkat', PT. Raja Grafindo Persada, Jakarta, 2004, hal. 14.
}

\section{Teknik Pengumpulan Data}

Pada sebuah penelitian, data merupakan bahan yang hendak digunakan untuk memecahkan masalah yang terdapat pada rumusan penelitian. Dengan demikian, bahan-bahan itu wajib terkumpul supaya masalah tersebut bisa diselesaikan. Jenis data dalam penelitian ini digolongkan ke dalam 2 jenis, yakni data sekunder serta data yang menggunakan teknik dalam menggunakan data melalui wawancara dengan narasumber yang berkaitan dengan permasalahan pada penelitian. Kemudian dilakukan studi dokumentasi. Penelitian dokumen ini dibutuhkan dalam menerangkan data yang sudah didapatkan serta menggali data tambahan yang dibutuhkan dari sumber lainnya. ${ }^{8}$ upaya itu dilaksanakan melalui pencarian serta pengumpulan data yang memiliki sifat sekunder ataupun primer dan berhubungan terhadap kebijakan dalam menanggulangi tindak pidana perjudian jenis sabug ayam pada daerah Polsek Kota Baru. Disamping itu juga dilengkapi dengan studi lapangan ke aparat penegak hukum dan ahli hukum yang memiliki perhatian terhadap kejahatan perjudian jenis sabung ayam.

\section{Analisa Data}

Analisis data merupakan sebua tahapan dalam mengumpulkan serta mengelompokan informasi sesuai dengan kategorinya yang maka penuis bisa menyeleksi ataupun mengevaluasi daya yang berhubungan ataupun tidak. Peneliti dalam penelitian ini memakai analisis deskripsitif pada data kualitatif yang secara umum memamaki perspekstif dengan rasioanl terhadap interpretasi, kompoarasi, deduksi, serta induksi.

\section{HASIL DAN PEMBAHASAN \\ Kebijakan Non Penal Dalam Pencegahan Tindak Pidana}

Penerapan kebijakan non penal lebih menitiktekankan terhadap tindakan pencegahan sebelum terjadinya kejahatan. Sasaran utamanya bagaimana kebijakan itu mampu menangani faktor-faktor penyebab terjadinya kejahatan tindak pidana perjudian dengan upaya "preventif" agar semua pihak bisa bergerak dan bersinergi terhadap permasalahan-permasalahan sosial yang secara langsung atau tidak langsung dapat menumbuh suburkan upaya perjudian di kalangan masyarakat.

Mengacu kepada sistematika kebijakan kriminal yang telah ada usaha-usaha kebijakan non penal dalam pencegahan dan perlindungan korban perdagangan orang (trafiking) menurut Muladi dan Barda Nawawi Arief dapat berupa : Penyantunan dan pendidikan sosial dalam rangka mengembangkan tanggung jawab sosial warga masyarakat, penggarapan jiwa masyarakat melalui

${ }^{8}$ Farouk Muhammad Dan H. Djaali, Metodologi Penelitian Sosial (Bunga Rampai), Penerbit PTIK Press, Jakarta, 2003, hal. 110. 
pendidikan moral, agama dan sebagainya, pengingkatan usaha-usaha kesejahteraan anak dan remaja, kegiatan patroli dan pengawasan lainnya secara kontiniu oleh polisi dan aparat kemanan lainnya. Usaha-usaha non penal ini dapat meliputi bidang yang sangat luas di seluruh sector kebijakan sosial. ${ }^{9}$

Pencegahan kejahatan (upaya non penal) memfokuskan diri pada campur tangan sosial, ekonomi dan pelbagai area kebijakan publik dengan maksud mencegah terjadinya kejahatan. Bentuk lain dari keterlibatan masyarakat, nampak dari upaya pencegahan situasional dan peningkatan kapasitas masyarakat dalam penggunaan sarana kontrol sosial informal. Peningkatan pencegahan kejahatannya berorientasi pada pelaku atau offender-centred crime prevention dan berorientasi pada korban atau victim-centred crime prevention. ${ }^{10}$

Tujuan utama dari usaha-usaha non penal bagaimana mampu memperbaiki kondisi-kondisi sosial tertentu, secara langsung mempunyai pengaruh preventif terhadap kejahatan. Upaya keseluruhan kegiatan preventif non penal itu memiliki kedudukan strategis dalam memegang posisi kunci yang seyogianya terus diintensifkan dan diefektifkan. Singkronisasi dalam acuan yaitu tujuan hukum, nilai-nilai keadilan, azas-azas hukum, konsep-konsep hukum dan norma hukum dari konsep hukum yang dilahirkan Undang-Undang Nomor 7 Tahun 1974 Tentang Penertiban Perjudian sebagai payung hukum kebijakan.

\section{Upaya Pendekatan Non Penal Terhadap Pelaku}

Mengingat upaya penanggulangan kejahatan lewat jalur "non penal" lebih bersifat tindakan pencegahan untuk terjadinya kejahatan, maka sasaran utamanya adalah menangani faktor-faktor kondusif penyebab terjadinya kejahatan. Faktor-faktor kondusif itu antara lain, berpusat pada masalah-masalah atau kondisikondisi sosial yang secara langsung atau tidak langsung dapat menimbulkan atau menumbuh suburkan kejahatan. Dengan demikian, dilihat dari sudut politik kriminal secara makro dan global, maka upaya-upaya nonpenal menduduki posisi kunci dan strategis dari keseluruhan upaya politik kriminal. Di berbagai Kongres PBB mengenai "The Prevention of Crime and Treatment of Offenders" ditegaskan upaya-upaya strategis mengenai penanggulangan sebab-sebab timbulnya kejahatan. ${ }^{11}$

Beberapa masalah dan kondisi sosial yang dapat merupakan faktor kondusif penyebab timbulnya kejahatan, jelas merupakan masalah yang tidak dapat diatasi semata - mata dengan "penal". Di sinilah keterbatasan jalur "penal" dan oleh karena itu, harus

${ }^{9}$ Refrensi Abintoro Prakoso, Kriminologi Hukum \& Hukum Pidana, Penerbit Laksbang Grafika, Yogyakarta, 2013, hal 159.

${ }^{10}$ Ibid., hal. 160

${ }^{11}$ M. Hamdan, Politik Hukum Pidana, Raja Grafindo Persada, Jakarta, 1997, hal. 20. ditunjang oleh jalur "nonpenal". Salah satu jalur "nonpenal" untuk mengatasi masalah-masalah sosial seperti dikemukakan diatas adalah lewat jalur "kebijakan sosial" (social policy). Kebijakan sosial pada dasarnya adalah kebijakan atau upaya-upaya rasional untuk mencapai kesejahteraan masyarakat. Jadi identik dengan kebijakan atau perencanaan pembangunan nasional yang meliputi berbagai aspek yang cukup luas dari pembangunan.

Salah satu aspek kebijakan sosial yang kiranya patut mendapat perhatian ialah penggarapan masalah kesehatan jiwa masyarakat (social hygiene), baik secara individual sebagai anggota masyarakat maupun kesehatan/ kesejahteraan keluarga (termasuk masalah kesejahteraan anak dan remaja), serta masyarakat luas pada umumnya. Penggarapan masalah "mental health", "national mental health" dan "child welfare" ini pun dikemukakan dalam skema Hoefnagels di atas sebagai salah satu jalur "prevention (of crime) without punishment" (jalur "nonpenal"). Prof. Sudarto pernah juga mengemukakan, bahwa "kegiatan karang taruna, kegiatan Pramuka dan penggarapan kesehatan jiwa masyarakat dengan pendidikan agama" merupakan upaya-upaya nonpenal dalam mencegah dan menanggulangi kejahatan.

Pembinaan dan penggarapan kesehatan jiwa masyarakat memang tidak berarti semata-mata kesehatan rohani/mental, tetapi juga kesehatan budaya dan nilainilai pandangan hidup masyarakat. Ini berarti penggarapan kesehatan masyarakat atau lingkungan sosial yang sehat (sebagai salah satu upaya nonpenal dalam strategi politik kriminal), tidak hanya harus berorientasi pada pendekatan religius tetapi juga berorientasi pada pendekatan identitas budaya nasional. Dilihat dari sisi upaya nonpenal ini berarti, perlu digali, dikembangkan dan dimanfaatkan seluruh potensi dukungan dan dan partisipasi masyarakat dalam upaya untuk mengektifkan dan mengembangkan "extra legal system" atau "informal and traditional system" yang ada di masyarakat.

Upaya nonpenal yang paling strategis adalah segala upaya untuk menjadikan masyarakat sebagai lingkungan sosial dan lingkungan hidup yang sehat (secara materiil dan immateriil) dari factor-faktor kriminogen. Ini berarti, masyarakat dengan seluruh potensinya harus dijadikan sebagai faktor penangkal kejahatan atau faktor "antikriminogen" yang merupakan bagian integral dari keseluruhan politik kriminal. Disamping upaya-upaya nonpenal dapat ditempuh dengan menyehatkan masyarakat lewat kebijakan sosial dan dengan mengali berbagai potensi yang ada di dalam masyarakat itu sendiri, dapat pula upaya nonpenal itu digali dari berbagai sumber lainnya yang juga mempunyai potensi efek-preventif. Sumber lain itu misalnya, media pers/media massa, pemanfaatan kemajuan teknologi (dikenal dengan istilah "technoprevention") dan pemanfaatan potensi efek-preventif 
dari aparat penegak hukum. Mengenai yang terakhir ini, Prof. Sudarto pernah mengemukakan, bahwa kegiatan patroli dari polisi yang dilakukan secara kontinu termasuk upaya nonpenal yang mempunyai pengaruh preventif bagi penjahat (pelanggar hukum) potensial. Sehubungan dengan hal ini, kegiatan razia/operasi yang dilakukan kepolisian di beberapa tempat tertentu dan kegiatan yang berorientasi pada pelayanan masyarakat atau kegiatan komunikatif edukatif dengan masyarakat, dapat pula dilihat sebagai upaya nonpenal yang perlu diefektifkan. ${ }^{12}$

\section{Kebijakan Non Penal Dalam Menanggulangi Tindak Pidana Perjudian Jenis Sabung Ayam Dalam Wilayah Hukum Kepolisian Sektor Kota Baru Saat Ini Dan Yang Akan Datang}

Problema penegakan hukum di Indonesia nampaknya mulai menghadapi kendala berkaitan dengan perkembangan masyarakat yang yang kian cepat. Berbagai kasus menggambarkan sulitnya penegak hukum mencari cara agar hukum nampak sejalan dengan norma masyarakat. ${ }^{13}$ Bagaimana pun juga masalah perjudian, baik itu menguntungkan atau merugikan, tidak dapat dilepaskan dengan manusia dan perilakunya dalam kehidupan bermasyarakat. Judi adalah salah satu hasil karya dan rekayasa manusia dalam memenuhi kebutuhan hidupnya baik secara rohani maupun secara jasmaniah di tengah masyarakat yang penuh dengan persaingan dan krisis serta tekanan. ${ }^{14}$

Judi pada hakekatnya dilarang dalam moral pancasila, keagamaan, serta kesusilaan dan bisa berbahaya untuk negara, masyarakat, serta bangsa apabila dilihat berdasarkan kepentingan nasionalnya. Judi memiliki pengaruh buruk yang dapat merusak mental serta moral masyarkatnya, terlebih penerus bangsa. Pada suatu sisi, perjudian yakni permasalahan sosial yang tidak mudah untuk ditanggulangi serta munculnya perjudian itu telah ada dimulai terdapatnya peradaban manusia. Perjudian jenis sabung ayam merupakan jenis penyakit manusia yang wajib dimusnahkan keberadaannya, dengan demikian dibutuhkan keikutesertaan masyarakatnya secara bersama-sama terhadap pihak polisi dalam memusnahkan seluruh jenis perjudian agar membentuk keteriban, kemananan, serta kesejahteraan masyarakat.

Sejumlah anggota masyarakat senang serta menerima memainkan perjudian, sedangkan ada sebagian yang tidak menyukai dan menolaknya bahkan

12 Barda Nawawi, Bunga Rampai Kebijakan Hukum Pidana (Perkembangan Penyusunan Konsep KUHP Baru), Cet.Ke-2, Kencana, Jakarta, 2010, hal. 16.

13 Eva Achjani Zulfa, Ketika Jaman Meninggalkan Hukum, http:www. pemantauperadilan.com.

${ }^{14}$ Hironnymus Jati, Kaum Miskin Mengais Pendapatan Lewat Judi, hingga menghindarinya dan beranggapan bahwa judi adalah tindakan yang tercela. Masyarakat yang seperti itu menginginkan hidup secara bersih \& baik terhadap seluruh tindakan yang tidak patut dilakukan ataupun kurang baik. Sehingga berdasarkan pemikiran peniliti bahwasannya opini masyarakat mengenai judi pada hidup keseharian masyarakat.

Hukum timbul pada lingkup kemasyarakatan serta bertumbuhkembang pada ranah tersebut, yang maka hukum berperan besar untuk mengelola korelasi antarindividu ataupun antarkelompok. Hukum berupaya memberi keadilan pada kehidupan masyarakat, yang maka dapat membuat keadilan serta ketertiban tercipta.

Berhubungan terhadap permasalahan kejahatan judi sabung ayam yang dialami di hari rabu tanggal 24 Juni 2020, peristiwa tersebut terjadi di sekitar Kelurahan Bagan Pete Kec. Alam Berajo Kota jambi yang kian merasuk serta merajalela hingga pada tingkatan kemasyarakatan yang terbawah wajar jika masalah tersebut tidak lagi diasumsikan selaku permasalahan kecil. Permasalahan perjudian yang lebih tepatnya dinamakan tindak kriminal ataupun kejahatan merupakan kewajiban seluruh pihaknya berpartisipasi untuk memberantas serta menanggulanginya hingga pada tingkatan tertinggi.

Kepolisian Sektor Kota Baru biasanya rutin melakukan patroli pada siang ataupun malam hari untuk menjaga keamanan serta ketertiban masyarakat, pada waktu melaksanakan patroli polisi mencurigai sebuah lokasi yang ramai lalu ketika dilaksanakan pengujian faktanya tengah berbuat sebuah tindak pidana judi. Lalu pihak polisi menyelenggarakan tindakan represif dalam bentuk arahan serta himbauan, tapi jika hal tersebut dialami dengan cara berulang, adapun ditindak tegas agar memberi efek jera untuk pelakunya.

Sesuai wawancara yang dilakukan penulis dengan narasumber dari Kepolosian Sektor Kota Baru yaitu dengan bapak Jefri Simamora mengenai kebijakan hukum pidana untuk upaya penanggulangan tindak pidana judi jenis sabung ayam pada daerah hukum Kepolisian Sektor Kota baru saat ini, kebijakan yang dilakukan Kepolisian dalam menanggulangi kejahatan perjudian saat ini antara lain: ${ }^{15}$

\section{KUHP (Kitab Undang-Undang Hukum Pidana)}

Sumber hukum pidana sudah diketahui ada yang tertulis serta ada juga yang tidak (hukum pidana adat). Agar individu bisa melihat seperti apa hukum mengenai sebuah permaslahan, jadi peraturan hukum itu wajib dibuat rumusannya. Begitu juga kondisi di hukum pidana. Rumusan peraturan hukum pidana yang tertulis ada pada Kitab Undang-Undang Hukum Pidana serta pada peraturan perundang-undangan lain. Judi adalah

15 Melwisren, Wawancara dengan narasumber Afrito Marbaro selaku Kepala Kepolisian Sektor Kota Baru, pada tanggal 29 Maret 2021 
sebuah delik (tindak pidana) yang mengganggu keamanan masyarakat. Judi pada Kitab Undang-Undang Hukum Pidana jenis "Sabung Ayam" di samping dilarang dengan tegas terhadap hukum positif (Kitab Undang-Undang Hukum Pidana). Hal tersebut bisa dilihat berdasarkan kebijakan pasal 542 Kitab UndangUndang Hukum Pidana, 542 Kitab Undang-Undang Hukum Pidana, serta pasal 303 KUHP lalu melalui terdapat UU No. 77 tahun 1974 terjadi perubahan pasal 303 bis Kitab Undang-Undang Hukum Pidana. Di Pasal 303 Kitab Undang-Undang Hukum Pidana yakni yang dikatakan permainan judi ialah masing-masing permainan, yang mana secara umum memungkinkan memperoleh keuntungan bergantung pada keberuntungan semata, dikarenakan lebih terlatih dalam permainannya ataupun lebih ahli. Seluruh taruhannya mengenai putusan permainan ataupun perlombaan lain merupakan hal yang terlarang, yang dijalankan pihak yang terlibat dalam lomba ataupun permainan, begitupun seluruh taruhan yang lain berdasarkan bentuk-bentuk tindak pidana judi menjadi sebuah tindak pidana dolus, yakni tindak pidana dengan unsur kesengajaan dikarenakan pada judi tidak terdapat unsur ketidaksengajaan ataupun kealpaan, pihak yang berjudi yakni secara mengetahui serta sadar secara jelas \& nyata bahwasannya dirinya tengah berjudi. Contoh perjudian ialah bertaruh mengenai permainan ataupun perlombaan lainnya, yang tidak diselenggarakan pihak yang ikut bermain ataupun berlomba tersebut, begitupun seluruh taruhan lainnya. Adapula yang dipidana berdasarkan pasal tersebut antara lain :

1. Memberikan peluang ataupun mengadakan permaian perjudian itu untuk penghasilan. Seseorang yang telah menjadi bandar yang yang mendirikan perusahaan judi, individu yang mencampuri hal tersebut pun ikut dipidana. Dalam hal ini, tempat judi tersebut tidak di tempat yang umum, walaupun pada daerah yang tidak terbuka ataupun kelompok yang tertutup sudah bisa, asalkan judi tersebut belum memperoleh perizinan oleh pihak berwenang.

2. Dengan unsur kesengajaaan memberikan kesempatan ataupun menyelenggarakan guna memainkan perjudian untuk umum. Dalam hal ini tidak harus selaku pencarian, namun wajib pada lokasi yang bisa dikunjungi umum ataupun tempat umum. Hal tersebut jika sudah mendapat perizinan oleh pihak berwenang, berarti tidak dipidana.

3. Ikut bermain perjudian selaku pencaharian.

Berdasarkan pasal 303 ayat (3), unsur-unsur tindak pidana judi antara lain:

1) Terdapat perbuatan

Arti dari perbuatan dalam hal ini ialah tiap-tiap tindakan pada sebuah perlombaan yakni yang dilakukan secara individu contohnya kodok ulo, main domino, serta dadu ataupun mainan lainnya yang tidak diselenggarakan pihak yang ikut memainkannya, contohnya sepakbola.

2) Memiliki sifat untung-untungan

Hal tersebut memiliki maksud yakni harapan dalam memenangkan yang secara umum bergantung terhadap nasib atapun untung-untungan. Lalu dapat pula menang dikarenakan kebiasaan ataupun kepintaran pemainnya.

3) Melalui pertaruhan barang ataupun uang.

Tiap-tiap perlombaan yang dilaksanakan secara individu ataupun bukan diselenggarakan pihak yang ikut berlomba ataupun bermain yang digunakan sarananya untuk pertaruhan barang ataupun uang.

4) Melawan hukum

Tiap-tiap perjudian wajib memperoleh perizinan dulu oleh pihak berwajib. Lalu jika jika sebuah perlombaan memperoleh perzinian, perjudian itu tidak termasuk tindak pidana.

\section{Undang-Undang Nomor Tahun 1974}

Secara umum, judi berlawanan dalam segi keagamaan, moral panacila, kesusilaan, serta mengancam hidup dalam lingkup kemasyarakatan, negara, serta bangsa. Tapi meninjau realita yang sekarang, judi pada seluruh jenisnya masih sering dilaksanakan. Dilihat berdasarkan kepentingan nasional, pengadaan judi memiliki dampak buruk serta dapat merusak mental ataupun moral masyarakatnya, terlebih penerus bangsa. Walaupun realitanya pun memperlihatkan bahwasannya hasil judi yang didapatkan Pemerintah dari daerah ataupun Pusat bisa dipakai dalam upaya-upaya membangun, tapi dampak negatifnya lebih banyak daripada positifnya. Dengan demikian dalam hal itu harus mengelompokkan seluruh jenis tindak pidana judi selaku kriminalitas serta memberatkan sanksinya, sebab sanksi saat ini nyatanya tidak membuat pelaku jera dan jadi tidak sesuai.

Berikutnya pada Pemerintah diwewenangkan agar menjadikan judi tertib berdasarkan jiwa serta tujuan UU tersebut, yakni melalui penerbitan peraturan perundangundangan yang dibutuhkan dalam hal tersebut. Yang maka diterbitkan aturan mengenai ketertiban judi antara lain :

\section{Pasal 1 \\ "Menyatakan seluruh tindak pidana perjudian selaku kejahatan".}

\section{Pasal 2}

1) Mengubah sebutan sanksi pada Pasal 303 ayat (1) Kitab Undang-undang Hukum Pidana, dari Hukuman penjara maksimal 2 tahun 8 bulan atau denda maksimal Rp. 90.000 menjadi hukuman penjara maksimal sepuluh tahun ataupun denda maksimal Rp.25.000.000.

2) Mengubah sebutan sanksi pada Pasal 542 ayat (1) Kitab Undang-undang Hukum Pidana, dari 
hukuman kurungan maksimal sebulan ataupun denda maksimal Rp45000, menjadi hukuman penjara maksimal 4 tahun ataupun denda maksimal Rp10.000.000.

3) Mengubah sebutan sanksi pada Pasal 542 ayat (2) Kitab Undang-undang Hukum Pidana, dari hukuman kurungan maksimal 3 bulan ataupun denda maksimal tujuh ribu lima ratus rupiah menjadi hukuman penjara maksimal 6 tahun atau denda maksimal Rp15.000.000.

4) Mengubah ancaman Pasal 542 menjadi Pasal 303 bis. Pasal 3 (1) Pemerintah membahas penertiban judi berdasarkan jiwa serta tujuan UU tersebut. (2) implementasi ayat (1) pasal tersebut dibahas melalui Peraturan Perundang-undangan.

\section{Pasal 4 \\ "Dihitung saat diberlakukannya peraturan Perundang-undangan untuk penertiban judi sebagaimana yang tercantum dalam Pasal $3 U U$ tersebut, mencabut Ordonansi tanggal 7 Maret 1912 (Staatsblad Tahun 1912 No.230) seperti yang sudah beberapa kali diubah serta ditambahkan, terakhir dengan Ordonansi tanggal 31 Oktober 1935 (Staatsblad Tahun 1935 Nomor 526)".}

\section{Pasal 5}

"UU tersebut diberlakukan saat tanggal diundangkan. Supaya tiap-tiap individu bisa mengetahui, memerintahkan UU tersebut melalui penempatannya pada Lembaran Negara Republik Indonesia".

Sesuai dengan hal itu, adapun untuk menertibkan judi, pasal 303 Kitab Undang-undang Hukum Pidana itu ditegaskan melalui Undang-Undang Nomor 7 1974, yang ada pada pasal 1, membahas seluruh tindak pidana perjudian selaku tindak pidana. Pada hal tersebut bisa diterangkan bahwasannya seluruh jenis perjudian yang tidak memperoleh perizinan termasuk tindak pidana namun terdapat pula yang berupa kejahatan (pasal 303 Kitab Undang-undang Hukum Pidana), berupa pelanggaran (pasal 542 Kitab Undang-undang Hukum Pidana) serta pasal 542 Kitab Undang-undang Hukum Pidana, lalu melalui terdapatnya Undang-undang Nomor 71974 diganti jadi pasal 303 bis Kitab Undang-undang Hukum Pidana. Pada pasal 2 ayat (1) Undang-Undang. Nomor 71974 hanya mengganti sanksi pasal 303 ayat (1) Kitab Undang-undang Hukum Pidana dari 8 bulan penjara ataupun denda maksimal seembilan puluh ribu rupiah jadi hukuman penjara maksimal sepuluh tahun ataupun denda maksimal dua puluh lima juta. Pada pasal 303 ayat (1)-1 Bis Kitab Undang-undang Hukum Pidana serta pasal 303 ayat (1)-2 Bis Kitab Undang-undang Hukum Pidana memberatkan sanksi untuk siapapun yang menggunakan kesempatan dan ikut bermain perjudian diberatkan jadi tahun penjara ataupun denda maksimal sepuluh juta rupiah dan ayat (2)-nya penjatuhan sanksi untuk siapapun yang pernah dihukum penjara berjudi maksimal enam tahun ataupun denda maksimal lima belas juta rupiah.

Sangat ironis jika dengan eksplisit hukum menyebutkan bahwasannya seluruh jenis "perjudian" tidak diperbolehkan tegas pada UU, tapi seluruh jenis praktek jadi boleh apabila memperoleh perizinan oleh pemerintah. Harus dipahami bahwasannya perjudian terdapat unsur; a) terdapatnya harapan dalam memenangkan kompetisi, b) memiliki sifat nasibnasiban, c) terdapat insentif dalam hadiah untuk yang memenangkannya, serta d) harapan agar menang lebih besar apabila terdapat aspek ketangkasan, kepintaran, serta kecerdasan. Dalam segi hukum individu yang bisa dipidana pada kasus judi, antara lain : 1) Perusahaan (badan hukum) ataupun Orang yang memberi kesempatan ataupun menyelenggarakan perjudian selaku pencaharian serta untuk siapa pun yang berintervensi pada judi baik selaku penyelenggaranya ataupun pemainnua. Lalu tentang tempatnya harus di tempat umum, meskipun tertutup, tapi bisa dipidana ; 2 Perusahaan (badan hukum) ataupun Orang dengan unsur kesengajaan memberikan kesempatan ataupun menyelenggaran perjudian untuk umum, dalam hal ini tidak harus dilakukan selaku mata pencahariaanya, asalkan di tempat ataupun yang bisa didatangi banyak orang, terkecuali terdapat perizinan oleh pemerintah judi bahwa tidak dipidana ; 3) individu yang menganggap perjudian sebagai pencaharian bisa dipidana; 4) Individu yang hanya turut dalam perjudian yang tidak selaku pencahariannya pun bisa dipidana. (vide, pasal 303 bis KUHP).

Kemudian dilanjutkan wawancara yang dilakukan penulis dengan narasumber dari Kepolosian Sektor Kota Baru yaitu dengan bapak Jefri Simamora mengenai kebijakan hukum pidana upaya penanggulangan tindak pidana judi jenis sabung ayam pada daerah hukum Kepolisian Sektor Kota baru yang akan datang, kebijakan yang dilakukan Kepolisian dalam menanggulangi kejahatan perjudian yang akan datang antara lain: ${ }^{16}$

Ditinjau berdasarkan segi "criminal policy", usaha dalam menanggulangi tindak pidana judi menjadi sebuah delik kesusilaan yang nyatanya tidak bisa dilaksanakan dengan sebahagian hukum pidana, namun wajib dilewati juga melalui pendekatan sistemik ataupun integral. Dengan demikian usaha dalam menaggulangi judi pun wajib melalui pendekatan dengan sifat edukatif, moralis, serta sosio kultural.

Usaha dalam menanggulangi tindak pidana di samping melalui pidana, namun tentu saja wajib mengedapankan usaha0usaha yang sifatnya

16 Melwisren, Wawancara dengan narasumber Afrito Marbaro selaku Kepala Kepolisian Sektor Kota Baru, pada tanggal 29 Maret 2021 
mengembangkan masyarakat. Tapi menjadikan sebuah kebijakan hukum dalam segi kesusilaan jadi sesuatu yang sulit, sebab di sinilah kadangkala peraturan perundang-undangan wajib bisa diposisikan di tempat yang sesuai berdasarkan patokan serta ukuran dan patokan mengenai sesuatu yang berkaitan dengan kesusilaan dan kemajuan IPTEK. Dengan demikian, pemerintah wajib menghadapi hal itu melalui perancangan suatu aturan yang bisa mengakomodir serta menjangkau tindak pidana dalam segi kesusilaan, terutama tindak pidana judi sabung ayam. Sehingga diperbaruinya Kitab Undang-undang hukum pidana menjadi sebuah hal yang harus dilakukan. Pemaparan pada Pasal itu di mana pada konsepsi Rancangan Undang-Undang Kitab Undang-undang Hukum Pidana 2015 Pasal 506 ayat (1) memaparkan bahwasannya individu yang memberikan kesempatan ataupun yang menawarkan agar memainkan perjudian serta membuat hal itu menjadi pencaharian, dengan demikian dihukum penjara maksimal sembilan tahun. Hal tersebutlah yang harus ditegaskan terutama untuk individu yang memberi peluang untuk individu lain agar melakukan perjudian, di sinilah judi tersebut timbul dikarenakan terdapat individu yang memberi peluang melakukan perjudian.

Pada penelitian ini, peneliti menyetujui terhada terdapatnya konsespsi RUU KUHP 2015 yang membahas tentang judi yang tercantum pada Pasal 506 ayat (1) \& (2) danPasal 507 yang membahas tentang Perjudian. Sebab pada Pasal itu secara tegas membahas tentang Perjudian yakni dari orang yang menawarkannya hingga yang ikut perjudian.

\section{Kebijakan Penerapan Hukum Yang Dilakukan Oleh Aparat Penegak Hukum Dalam Upaya Penanggulangan Tindak Pidana Perjudian Jenis Sabung Ayam Di Wilayah Hukum Kepolisian Sektor Kota Baru}

UU No. 7 Tahun 1974 mengenai Penertiban Perjudian bahwasannya yang memberatkan hukuman pidana pada pemain serta bandar perjudian terlihat niat membentuk UU tersebut oleh pihak pemerintah, yang maka bisa dinyatakan pemerintahl yang memiliki iktikad baik tersebut. Meninjau perumusan aturan hukum pidana itu artinya sangat jelas bahwasannya judi tidak diperbolehkan hukum pidana dikarenakan sudah sesuai dengan perumusan sebagaimana yang dimaksudkan, maka bisa diketahui sanksi pidana yang implementasinya dilakukan berdasarkan hukum acara pidana. Pada realitanya, bahwasannya perjudian mengalami perkembangan dan sukar diatasi, dimusnah, sebagaimana judi pada tempat terbuka, tempat umum, adapun yang dilaksanakan dengan terselubung, terorganisir, serta beragam yang dilaksanakan pemain judi yang sesungguhnya tidak diperbolehkan. Upayaupaya yang telah dilakukan anggota Kepolisian Sektor Kota Baru melalui bantuan masyarakat dibuktikan efektif untuk upaya penanggulangan tindak pidana judi jenis sabung ayam yang ada pada daerah hukum Kepolisian Sektor Kota Baru.

Sesuai wawancara dengan Kepolisian Sektor Kota Baru yaitu Bapak Afrito Marbaro, mengenai kebijakan penerapan hukum yang dilaksanakan pihak penegak hukum untuk menanggulangi tindak pidana judi jenis sabung ayam pada daerah hukum Polsek Kota Baru, menurut bapak Afiro mengatakan bahwa upaya yang dilakukan kepolisian yaitu: ${ }^{17}$

\section{Upaya Pre-emtif}

Upaya pre-emtif ialah usaha dalam menghimbau pelaku judi jenis sabung ayam supaya sadar lalu tidak lagi berjudi sebab tentunya akan meresahkan masyarakatnya yang tidak menjadi aman ataupun tertib. Pada usaha tersebut, polisi menghimbau pelakunya melalui:

a. bersosialisasi di bidang ketertiban masyarakat

Tidak sedikit warga yang tidak memahami mengenai judi yang dilakukan tersebut adalah termasuk sebuah tindak pidana kejahatan, hal tersebut dilaksanakan supaya masyarakatnya dapat memilah sesuatu yang wajib dihindari agar tidak masuk pada permainan itu.

b. Meningkatkan kesadaran masyarakat untuk lebih mentaati hukum yang berlaku

Semua bentuk kejahatan pasti ada hukum yang berlaku untuk mengaturnya. Masyarakat terkesan masih menganggap remeh tentang hukum yang berlaku saat ini. Misalnya dalam kasus perjudian ini hukuman yang diberikan masih tergolong ringan sehingga masyarakat tidak merasa takut apabila melakukan perjudian.

c. Membina hubungan baik antara masyarakat dengan kepolisian setempat

Hal ini bertujuan agar terciptanya realisasi perlindungan itu sendiri dengan tujuan agar masyarakat selalu berperan aktif dalam menjaga lingkungan tetap aman supaya lingkungan dimana bertempat tinggal maupun tempat kerja tersebut terhindar dari citra buruk perjudian.

\section{Upaya Preventif}

Upaya preventif untuk penanggulangan sebagai dasar dalam memberantas tindak pidana perjudian di Wilayah Hukum Kepolisian Sektor Kota Baru. Aparat kepolisian memberantas dan menanggulangi secara Preventif dengan berbagai upaya, antara lain:

a. Mengadakan penyuluhan Hukum

Untuk mengurangi tindak pidana yang masih terjadi, maka perlu diadakan penyuluhan hukum kepada masyarakat. Penyuluhan hukum adalah suatu sarana untuk memberikan informasi dan pemahaman terhadap norma-norma dan peraturan undang-undang yang berguna untuk mewujudkan kesadaran

17 Melwisren, Wawancara dengan narasumber Jefri Simamora selaku Kasubag Humas Kepolisian Sektor Kota Baru, pada tanggal 29 Maret 2021 
masyarakat terhadap hukum sehingga menciptakan masyarakat yang taat kepada norma hukum yang berlaku.

b. Mengadakan pengawasan

Pengawasan yang dilaksanakan oleh pihak kepolisian dilakukan pada daerah yang sering ramai, tempat umum, dan tempat terpencil.

c. Melakukan Patroli dan penjagaan terhadap masyarakat.

Kepolisian Sektor Kota Baru menempatkan personil kepolisian untuk melakukan patroli di sekitar wilayah tersebut. Hal itu umumnya dilaksanakan oleh jajaran anggota dan BABINSA yang bertujuan untuk menertibkan penyakit masyarakat yang sudah marak terjadi yaitu perjudian jenis sabung ayam. Patroli yang dilakukan oleh Pihak Kepolisian biasanya menyisir tempat-tempat yang sering dilaporkan oleh masyarakat karena adanya kegiatan yang dicurigai sebagai tindak pidana perjudian.

d. Berkoordinasi oleh pihak kelurahan RT/ RW agar biasa mensosialisasikan kepada warga masyarakat.

Dengan tagar mengayomi dan melayani masyarakat, Kepolisian ikut turun serta ke dalam kehidupan sosial masyarakat dan berkoordinasi dengan pejabat sekitar untuk melakukan sosialisasi mengenai dampak perjudian serta berkerjasama untuk menjaga kondusifitas lingkungan.

e. Melakukan Razia

Diadakannya razia di berbagai daerah yang sering dilakukan sebagai tempat untuk bermain judi dapat menjadi salah satu cara untuk mengurangi perjudian yang terjadi.

\section{Upaya Represif}

Upaya Represif merupakan upaya atau tindakan yang dilakukan secara langsung untuk memberantas kejahatan dengan memberikan tindakan agar pelaku jera dan tidak mengulangi kejahatannya kembali. Adapun tindakan Represif yang dimaksud adalah sebagai berikut: a. Menerima dan mengambil tindakan terhadap laporan atau pengaduan adanya tindak kejahatan yang terjadi di masyarakat, supaya pihak kepolisian bisa langsung melakukan penggrebekan tempat perjudian tersebut dan menangkap para pelaku perjudian.

b. Melakukan serangkaian tindakan penyelidikan dan penyidikan terhadap suatu kejahatan perjudian agar bisa diproses lebih lanjut supaya para pelaku jera dan bisa diproses langsung, dan menimbulkan kenyamanan untuk masyarakat setempat.

c. Melakukan penangkapan pelaku perjudian yang tertangkap basah sedang bermain serta pemeriksaan dan penahanan oleh polsek setempat sebelum dinaikkan ke Polres.

Apabila sekiranya dapat dilanjutkan maka selanjutnya berkas perkara akan di limpahkan ke Kejaksaan untuk dilakukan penuntutan agar nantinya mereka yang terlibat dalam kejahatan perjudian dapat dikenakan hukuman melalui proses persidangan. Setiap langkah para penegak hukum untuk memenuhi keamanan masyarakat pasti akan disambut baik oleh semua pihak. Pada umumnya pola-pola penanggulangan perjudian menekankan prinsip bahwa penindakan terhadap pelaku perjudian dalam bentuk bagaimanapun harus menimbulkan efek jera agar kejadian tersebut tidak terjadi lagi mengingat pelakunya adalah masyarakat umum dimana pelaku tersebut dapat dikatakan sebagai tersangka.

\section{SIMPULAN}

Sesuai dengan hasil pembahasan di atas maka penulis menarik kesimpulan dari uraian pembahasan antara lain:

1. Kebijakan hukum pidana penanggulangan perjudian jenis sabung ayam di Kitab Undang-Undang Hukum Pidana judi telah diatur pada Pasal 303 bis dan aturan perida pidananya ialah empat tahun penjara. Yang mana perjudian ialah sebuah permainan yang mempertaruhkan benda berharga ataupun uang untuk taruhan. Peristiwa ini yang meebuat perjudian sebagai sebuah tindak pidana sebab masing-masing permainan yang dilaksanakan dengan memakai uang untuk taruhan itu disebut dengan perjudian. Sedangkan untuk yang akan mendatang yaitu dengan dilakukan pembaharuan pada Rancangan UndangUndang KUHP adalah sebuah keharusan sebab pemerintah harus menyikapi perkembangan tersebut dengan merencanakan suatu aturan yang bisa mencakup serta dapat mengurangi kejahatan di bidang kesusilaan terutama tindak pidana perjudian jenis sabung ayam. Sehingga, hal semacam ini dibutuhkan kemitraan antara penegak hukum dengan anggota masyarakat dalam menanggulangi tindak pidana Perjudian supaya menciptakan keadaan sosial yang aman dan bersih dari perjudian yang meresahkan masyarakat.

2. Kebijakan penerapan hukum yang dilakukan oleh aparat penegak hukum dalam upaya penanggulangan tindak pidana perjudian jenis sabung ayam di wilayah hukum Kepolisian Sektor Kota Baru dilakukan dengan upaya pre-emtif yaitu dengan memfokuskan pada upaya dengan himbauan pada para pelaku perjudian jenis sabung ayam supaya memiliki kesadaran serta tidak melaksanakan perjudian lagi sebab kemungkinan akan mengganggu keamanan dan ketertiban masyarakat sekitar. Kemudian dengan upaya preventif untuk penanggulangan sebagai dasar dalam memberantas tindak pidana perjudian di Wilayah Hukum Kepolisian Sektor Kota Baru. Selanjutnya melalui upaya Represif yang merupakan suatu tindakan yang dilakukan secara langsung untuk memberantas kejahatan dengan memberikan tindakan agar pelaku jera dan tidak mengulangi kejahatannya kembali. 


\section{DAFTAR PUSTAKA}

Abintoro Prakoso, Kriminologi Hukum \& Hukum Pidana, Penerbit Laksbang Grafika, Yogyakarta, 2013.

Anton Tabah, Menatap Dengan Mata Hati Polisi Indonesia, PT Gramedia Pustaka Utama, Jakarta, 1991.

Amiruddin \& Zainal asikin, pengantar Metode Penelitian Hukum, Raja Grafindo Persada, Jakarta, 2012.

Barda Nawawi Arief, Bunga Rampai Kebijakan Hukum Pidana, PT. Citra Aditya Bakti, Bandung, 2005. Masalah Penegakan Hukum dan Kebijakan Hukum Pidana dalam Penanggulangan Kejahatan, Kencana Prenada Media Group, Jakarta, 2007.

Farouk Muhammad Dan H. Djaali, Metodologi Penelitian Sosial (Bunga Rampai), Penerbit PTIK Press, Jakarta, 2003.

https://id.scribd.com/doc/99081468/Seluk-Beluk-AyamAdu-unggas-Pada-Umumnya, diakses pada tanggal 1 Maret 2021

Muladi dan Barda Nawawi Arief, Teori-Teori dan Kebijakan Pidana, Alumni, Bandung, 2010.

Moempoeni Martojo, Politik Hukum dalam Sketsa, Fakultas Hukum Undip, Semarang, 2000.

Moh. Mahfud MD, Pergulatan Politik dan Hukum di Indonesia, Gama Media, Yogyakarta,1999.

Soeryono Soekarto, Pengantar Penelitian Hukum, UI Press, Jakarta, 1984.

Soerjono Soekanto dan Sri Mamuji, Penelitian Hukum Normatif 'Suatu Tinjauan Singkat', PT. Raja Grafindo Persada, Jakarta, 2004.

Sudarto, Hukum dan Hukum Pidana, Penerbit Alumni, Bandung, 1977.

Undang-Undang Dasar (UUD) Tahun 1945

Kitab Undang-Undang Hukum Pidana Indonesia (KUHP)

Kitab Undang-Undang Hukum Acara Pidana (KUHAP)

Undang-Undang Nomor 7 Tahun 1974 Tentang Penertiban Perjudian. 